\title{
EMIGRACYJNE ESEJE (?) JERZEGO PIETRKIEWICZA
}

\author{
Józef OLEJNICZAK (Uniwersytet Śląski w Katowicach) \\ ORCID: 0000-0002-6831-5100
}

W 41. numerze redagowanych przez Mieczysława Grydzewskiego w Londynie „Wiadomości Polskich" Kazimierz Wierzyński opublikował obszerny artykuł Poezja polska na emigracji ${ }^{1}$. Otworzył $\mathrm{w}$ ten sposób najistotniejszy być może spór, jaki w połowie $\mathrm{XX}$ wieku, w obliczu toczącej się wojny oraz początku konstytuowania się polskiej diaspory literackiej, toczył się w literaturze polskiej. Warto tu przypomnieć cztery cechy sytuacji polskiej kultury w obliczu wojny i późniejsze rozstrzygnięcia wskazywane przez Wierzyńskiego:

1. Zawężenie perspektywy do twórczości poetyckiej tworzonej przez poetów znajdujących się na obczyźnie, zwykle towarzysko powiązanych z grupą Skamandra, a także do tradycji polskiego romantyzmu, głównie romantyzmu Wielkiej Emigracji;

2. Podjęcie próby przeniesienia hierarchii poezji międzywojnia, z dominującą rolą Skamandra, w nową rzeczywistość (toczącej się wojny i diaspory), a co za tym idzie ignorowanie twórczości poetów łączonych z wieloma odłamami literackich awangard;

3. Apologia poezji przyjaciela Wierzyńskiego - Jana Lechonia, jako poetyckiego wzorca i dzieła najwyższej próby;

4. Skłonność do — jak określiła to Maria Danilewicz-Zielińska — „wspominkarstwa”, a co za tym idzie idealizacja rzeczywistości II Rzeczpospolitej.

Spór o kształt polskiej poezji i - szerzej - literatury emigracyjnej będzie się w publicystyce emigracyjnej toczył do połowy lat 60 ., co w badaniach literatury polskiej minionego wieku było wiele razy opisywane ${ }^{2}$. Nie to jest jednak tematem niniej-

\footnotetext{
${ }^{1}$ K. Wierzyński, Poezja polska na emigracji, Wiadomości Polskie, Polityczne i Literackie $1943 \mathrm{nr}$ 41(187), s. 2.

${ }^{2}$ Dyskusję o kształcie poezji polskiej na emigracji podsumował np. W. Wyskiel, zob.: Wprowadzenie do tematu: literatura i emigracja, [w:] Pisarz na obczyźnie, red. T. Bujnicki, W. Wyskiel, Wrocław-Warszawa-Kraków-Gdańsk-Lódź 1985; wiele miejsca tej problematyce poświęcono także w dwóch podstawowych opracowaniach literatury emigracyjnej powstałych na
} 
szego szkicu. Chodzi w nim o szybką odpowiedź udzieloną Wierzyńskiemu, a opublikowaną w „Myśli Polskiej” przez Jerzego Pietrkiewicza - świeżo przybyłego ze Szkocji, gdzie na uniwersytecie w St. Andrews uzyskał tytuł magistra literatury angielskiej i niemieckiej, do Londynu. Pisarz rozpoczął studia doktoranckie na Uniwersytecie Londyńskim i pracę nad rozprawą doktorską z historii poezji angielskiej, którą ukończył z powodzeniem w 1947 roku. Już tytuł owej odpowiedzi był znaczący: Poezja ułatwiona. K. Wierzyńskiemu w odpowiedzi. Dwa krótkie cytaty z artykułu Pietrkiewicza wystarczą za charakterystykę jego polemicznego tonu:

Artykuł Kazimierza Wierzyńskiego, członka Akademii Literatury, o poezji polskiej na emigracji nie jest szkicem krytycznym, ale impresją liryczną o charakterze panegirycznym. Wiadomo, że K. Wierzyński należał do Skamandra, że Tuwim, Słonimski, Wittlin, Lechoń i Baliński to jego starzy przyjaciele; z pewnym przeto zażenowaniem czyta się ten artykuł, w którym przyjaciel nazywa przyjaciela genialnym pisarzem, a utwory jego arcydziełami. [...]

Oczywiście wolno Wierzyńskiemu uwielbiać przyjaciela Lechonia, a Lechoniowi przyjaciela Wierzyńskiego. To już kwestia ich poczucia taktu i metod reklamowych wydawcy pisma.

Wierzyński jednakże poruszył mimochodem sprawy, które ważniejsze są nawet od tego osobliwego - iście cudownego - zjawiska, że wśród jego przyjaciół co poeta to geniusz; sprawy te dotyczą samej już istoty poezji, jej źródeł i wpływu na czytelnika, jej tworzywa i formy wypowiedzi ${ }^{3}$.

Łatwo zauważyć naiwność i — trzeba to dopowiedzieć — złośliwość tej polemiki, program poezji polskiej na emigracji Wierzyńskiego też zresztą charakteryzował się naiwnością i - napisałbym - „łatwością”, sądów i ocen; szczególnie gdy wraca się do tych tekstów współcześnie, po lekturze wypowiedzi takich pisarzy, jak: Melchior Wańkowicz (Klub Trzeciego Miejsca ${ }^{4}$ ), Gustaw Herling-Grudziński (wstęp do rzymskiego wydania Ksiag narodu polskiego i pielgrzymstwa polskiego Adama Mickiewicza ${ }^{5}$ ), Witold Gombrowicz (Przeciw poetom, fragm. Dziennika ${ }^{6}$ ), Józef Wittlin (Blaski i nędze wygnania $^{7}$ ) czy Czesław Miłosz (Noty o wygnaniu ${ }^{8}$, Prywatne obowiazki wobec polskiej literatury ${ }^{9}$ ) oraz po lekturze wielu prób naukowych i krytycznych syntez poezji polskiej drugiej połowy XX wieku. Jednak w szkicu Pietrkiewicza pojawia się ton nieobecny w polskiej publicystyce literackiej przed 1943 rokiem, a i we współczesnej trudno się przebijający: by porzucić $\mathrm{w}$ dyskusjach o polskiej poezji paradygmat narodowy, a spojrzeć na nią z perspektywy uniwersalnej, w kontekście zjawisk literatury Zachodu; w przypadku Pietrkiewicza chodzi głównie o poezję anglosaską. W histo-

obczyźnie: M. Danilewicz-Zielińska, Szkice o literaturze emigracyjnej, Paryż 1978 i Literatura polska na obczyźnie 1940-1960, t. 1-2, red. T. Terlecki, Londyn 1965.

${ }^{3}$ J. Pietrkiewicz, Dla pokrzepienia mózgów. Szkice literackie z lat 1940-1948. Nowoczesność w tradycji. Essay o poezji. Trust the trees, wybór B. Czarnecka, Torun 2002, s. 31, 32; wszystkie cytaty z eseistyki Pietrkiewicza pochodzą z tej edycji, zaznaczam je w tekście głównym w następujący sposób: (JP, s. ...).

${ }^{4}$ M. Wańkowicz, Klub Trzeciego Miejsca, Paryż 1949.

${ }^{5}$ A. Mickiewicz, Księgi narodu polskiego i pielgrzymstwa polskiego, Rzym 1946.

${ }^{6}$ Zob.: W. Gombrowicz, Przeciw poetom, [w:] tegoż, Dziennik 1953-1956, red. J. Błoński, Kraków 1986, s. 339-351; pierwodruk w paryskiej Kulturze $1951 \mathrm{nr} 10$.

${ }^{7}$ J. Wittlin, Blaski i nędze wygnania, [w:] tegoż, Orfeusz w piekle XX wieku, Paryż 1963.

${ }^{8}$ Cz. Miłosz, Noty o wygnaniu, Kultura 1981, nr 3(402).

${ }^{9}$ Tenże, Prywatne obowiazki wobec polskiej literatury, [w:] tegoż, Prywatne obowiazki, Paryż 1972 . 
rycznym, politycznym i literackim momencie, gdy powstawał ten tekst, jego tezy brzmiały mocno, były wręcz obrazoburcze.

W znakomitym eseju Liryka i nowoczesność Paula de Mana (ogłoszonym w roku śmierci de Mana - 1983) można przeczytać m.in.:

W teorii kwestię tego, co nowoczesne, można postawić w odniesieniu do wszelkiej literatury w każdym czasie, współczesnym albo minionym. Jednak w praktyce kwestia musi być stawiana nieco bardziej pragmatycznie z takiego punktu widzenia, który postuluje zasadniczo współczesną perspektywę i faworyzuje literaturę nowszą ${ }^{10}$.

Taki jest (w dużym skrócie) punkt wyjścia rozważań na temat sporów o nowoczesność w sztuce i poezji toczonych we wszystkich nieomal odłamach dwudziestowiecznych awangard. Przypominam ten fragment, by pokazać bliskość - tego punktu wyjścia, ale i tez eseju — oraz konkluzji zawartych w późniejszym o dwa lata (1945) szkicu Pietrkiewicza Nowoczesność w tradycji. Myśl de Mana święci we współczesnej humanistyce triumfy, jest on jednym z najważniejszych (może najważniejszym z punktu widzenia literaturoznawstwa) teoretyków postmodernizmu i krytyków kultury (i literatury) modernistycznej. Pietrkiewicz jest we współczesnym dyskursie humanistycznym właściwie nieobecny, a zbieżności z de Manem są zastanawiające! Nie chcę jednak sugerować, że omawiany autor w jakimkolwiek stopniu jest prekursorem czy że antycypuje polski postmodernizm (wtedy słusznie dałbym się ,złowić” Włodzimierzowi Boleckiemu $^{11}$ ).

Pietrkiewicz w wielu szkicach, co naturalne, podejmuje refleksję nad kondycją pisarza emigracyjnego i statusem literatury na wygnaniu. Może warto się pokusić o namysł nad refleksją pisarza w kontekście najważniejszych polskich wypowiedzi na ten temat - Wańkowicza, Herlinga-Grudzińskiego, Gombrowicza, Wittlina, Miłosza?...

Gdy połączyć te dwa główne wątki eseistyki Pietrkiewicza - pytania o nowoczesność poezji i o status literatury emigracyjnej — to można, moim zdaniem, podjąć próbę innego umiejscowienia dyskursu o polskiej literaturze emigracyjnej i - szerzej - po prostu o polskiej poezji i o wydobyciu tegoż dyskursu z polonocentryzmu z jednej strony, a polskich kompleksów z drugiej. Pietrkiewicz podjął taką próbę jako jeden z pierwszych w polskiej kulturze, chociaż brakowało mu konsekwencji. Muszę zastrzec, że nie była to próba udana, nie doczekała się zresztą szerokiej dyskusji nawet $\mathrm{w}$ prasie emigracyjnej.

Jakie były powody? Myślę o paru. Nie był Pietrkiewicz mistrzem nieukształtowanego, permanentnie „niegotowego” gatunku literackiego, jakim jest esej. Większość jego publicystycznych tekstów stanowi konsekwencję kompromisu, na który pisarz się zdecydował - między akademickim stylem prac naukowych a temperamentem poety i pisarza. Ale też kompromisu między potrzebą uczestnictwa w polskim życiu literackim na emigracji (stąd, jak sądzę, polemiczny charakter wielu szkiców) a poczuciem wykluczenia ze środowiska polskich emigrantów lub co najmniej świadomością niesprawiedliwego funkcjonowania na jego obrzeżach. Kolejny problem wynika, moim zdaniem, z dwujęzyczności Pietrkiewicza i — tu paradoks - jego stosunkowo mocnej pozycji w środowisku angielskich badaczy literatury, przede wszystkim slawistów. Wiem, że mogło to zabrzmieć obrazoburczo, jako sugestia, iż wysokie kompetencje Pietrkiewicza - językowe, kulturowe, filologiczne, historycznoliterackie - oraz imponująca erudycja, miały wpływ na jakość, czy może skromniej — moją ocenę, jego

\footnotetext{
${ }^{10}$ Literatura na świecie 1999 nr 10/11.

${ }^{11}$ Aluzja do tytułu i tez książki Włodzimierza Boleckiego Polowanie na postmodernistów (w Polsce), Kraków 1998.
} 
publicystyki. Zdaję sobie sprawę, że łatwo znaleźć, także w literaturze polskiej, przykłady, jak owe kompetencje budują artyzm, czasem nawet arcydzielność eseistyki... Jerzy Stempowski, Józef Wittlin, Aleksander Wat, Czesław Miłosz, Bolesław Miciński, Kazimierz Wyka, Stanisław Vincenz - to pierwsze przykłady twórców ,polskiej szkoły eseju", jakie potrafię wymienić. W końcu — by zakończyć wyliczenie przyczyn, dla których nie uważam eseistycznego (wolałbym napisać: publicystycznego) dorobku Pietrkiewicza za udany projekt — chodzi też o uwikłanie wielu szkiców w spory, które kolokwialnie określamy jako dyskusje na temat „słoń a sprawa polska”. Gdy autor Pogrzebu Europy podejmuje próby syntezy czy oceny polskiej literatury i kultury, albo gdy polemizuje $\mathrm{z}$ innymi przedstawicielami polskiej literatury (z zasady przebywającymi na emigracji) na temat ich ocen i syntez, to niejako przechwytuje dyskurs i posługuje się (tyle że zwykle odwracając wektory) tymi samymi argumentami. To trochę tak, jakby Witold Gombrowicz, kreśląc w Dzienniku krytyczny obraz dwudziestolecia międzywojennego, czynił to językiem i w horyzoncie argumentów, na przykład, Jana Lechonia... Tak dzieje się w moim przekonaniu w następujących szkicach Pietrkiewicza: Poezja ułatwiona, Patriotyzm wspominkarski, Zadania literatury na emigracji, Piśmiennictwo polskie na uchodźstwie, Przeciw sentymentalizmowi czy Wielkość i prowincjonalizm literatury polskiej ${ }^{12}$. Trzeba przyznać, że jak na ten niezbyt przecież obszerny dorobek publicystyczny, jest tego całkiem sporo.

Dość utyskiwań na przedmiot niniejszego szkicu, bo znajduję wśród esejów Pietrkiewicza także fragmenty odkrywcze, oryginalne, przekraczające ramy doraźnych polemik. A esej Nowoczesność w tradycji (1946) oceniam jako tekst wybitny, mówiący o polskiej i europejskiej poezji modernistycznej rzeczy ważne i ciągle aktualne.

Tezą mojego szkicu jest zgodność poezji nowoczesnej z istotą tradycji europejskiej, ale zgodność ta wymaga unaocznienia, uplastycznienia wobec nieufnej opinii przez zastosowanie umiejętnego procesu eliminacji. Manifesty, jak i wszystkie obietnice, zaprzysięgane w chwilach chełpliwych, pozostawiły po sobie osad uprzedzeń, który obrastał w kompleksy, nieuniknione w stosunkach między artystami i konsumentami sztuki (JP, s. 48)

— pisze na początku eseju Pietrkiewicz. I - trzeba przyznać — blisko tej deklaracji, jako manifestowi poety, do banału, wiele razy powtarzanego przez poetów i ich badaczy. Że nowoczesne jest to, co jest osadzone w tradycji, co z tradycji wyrasta... Że odwieczne są uprzedzenia, urazy i kompleksy w relacjach między poetami i ich komentatorami... Ale autor Pogrzebu Europy (notabene pierwodruk omawianego eseju stanowił autorski wstęp tej ważnej książki ${ }^{13}$ ) po pierwsze dostrzega podstawowe paradoksy poezji nowoczesnej (nowatorstwo zawsze musi być zakorzenione w tradycji; historia wypiera, eliminuje z pamięci zbiorowej większość dzieł; modernistyczna skłonność do formułowania manifestów i programów literackich nie wpływa na ewolucję poezji, a przeciwnie - pogłębia rozdźwięk między piszącymi a czytającymi), a po drugie bez pychy podejmuje próbę znalezienia w owych paradoksach sensu poezji oraz przyczyn jej trwania w historii i zbiorowej świadomości świata Zachodu. Te paradoksy znamy skądinąd, wystarczy sięgnąć do esejów i programu poezji cenionego przez Pietrkiewicza Thomasa Stearnsa Eliota, wspominanego tu na początku Paula de Mana

${ }^{12}$ Wszystkie wymienione eseje znaleźć można w edycji, której adres bibliograficzny podałem w przypisie nr 2.

${ }_{13}^{13}$ J. Pietrkiewicz, Pogrzeb Europy, Londyn 1946. 
czy prac Maurice’a Blanchota, głównie do Przestrzeni literackiej ${ }^{14}$. Ale Pietrkiewicz w rozważaniach o poezji idzie własną, bardzo osobną drogą. Nie chcę napisać, że idzie dalej niż wymienione tu wielkie postaci humanistyki modernistycznej. Ale tam, gdzie żarliwie broni sensu uprawiania sztuki poetyckiej i sensu obecności poezji w zbiorowej świadomości Europy, będącej trwałym składnikiem europejskiej tożsamości (jeśli taka w ogóle istnieje, by przypomnieć zastrzeżenie zgłoszone przez Haydena White'a ${ }^{15}$ ), sięga (w 1946 roku, przypominam) do argumentów, jakich użyła „nowa humanistyka” w dobie milenijnego przełomu, przynajmniej w jej nurcie ,postsekularnym”. Na przykład wtedy, gdy konstruuje subtelną paralelę między poezją i religią:

Poezji zawsze groziła śmierć i może dlatego właśnie jest nieśmiertelna. Poezja zawsze była nowoczesna i może dlatego właśnie jest najbardziej tradycjonalna ze wszystkich sztuk. Poezja przejmowała szybko osiągnięcia techniki i może dlatego właśnie wciąż przeciwstawia łaski pełną naiwność zarozumiałemu postępowi i zmechanizowanemu prostactwu. [...] konflikt poezji ze światem jest błogosławienie nieuniknionym konfliktem paradoksu z jednoznaczną tępotą rzeczywistości. Poezja będzie zdumiewać i oburzać ową pozorną niezrozumiałością, tak jak religia oślepia podwójnością swoich znaczeń. $[\ldots]$

Czy więc poezja uzupełnia religię? Może tak... Ale to nie ma istotnego znaczenia. Jedno pewne: tam gdzie religia milczy, a filozofia nie wie, tam poe zj a do myśla si ę (Nowoczesność w tradycji, JP, s. 49, podkreśl. — J. O.].

Naiwna to i anachroniczna wiara w poezję? Nie! Przeciwnie — Pietrkiewicz dokonuje tego aktu wiary w momencie, gdy kultura Zachodu po doświadczeniu Auschwitz w poezję zwątpiła, gdy dramatyczne pytania o sens poezji zadawał Theodor Adorno, a Witold Gombrowicz swoją filipikę kierował Przeciw poetom. Poezja ocalała i dawała ocalenie, choćby za sprawą wierszy Paula Celana, Tadeusza Różewicza czy Czesława Miłosza... Sądzę, że intuicje Pietrkiewicza nie były odległe od tych trzech wielkich, chociaż przecież bardzo się od siebie różniących, projektów poetyckich.

Podobnie nowocześnie brzmią rozważania Pietrkiewicza na temat sytuacji poezji w kontekście technologicznego rozwoju (film, radio, telewizja), którego nie odczuwa on jako zagrożenia dla poezji, ale jako szansę jej rozwoju (Nowoczesność $w$ tradycji, JP, s. 50), co świetnie współbrzmi przecież z tezami Josepha Hillisa Millera ${ }^{16}$. Nowoczesny wydaje się również krytyczny fragment o kontekście „modnych teorii naukowych" (tu Pietrkiewicz daje przykłady związków powieści Marcela Prousta z filozofią Henri Bergsona, psychoanalizy Sigmunda Freuda z odwiecznym w literaturze motywem snu oraz wpływu teorii względności Alberta Einsteina na współczesną powieść) (Nowoczesność $w$ tradycji, JP, s. 49-50), ponownie współbrzmiący z tezami Hillisa Millera:

Jednym z symptomów nadchodzącej śmierci literatury jest stadna ucieczka młodszych badaczy z wydziałów literaturoznawstwa na całym świecie od studiów nad literaturą do teorii, studiów kulturowych i postkolonialnych, medioznawstwa (film, telewizja etc.), studiów nad kulturą popularną, studiów kobiecych, studiów afrykańsko-amerykańskich etc. Częstokroć piszą i wykładają w sposób bliższy naukom społecznym niż tradycyjnie pojmowanej humanistyce. Ich pisarstwo i nauczanie często marginalizuje lub ignoruje

\footnotetext{
${ }^{14}$ M. Blanchot, Przestrzeń literacka, przeł. T. Falkowski, Warszawa 2016; pierwsze wydanie francuskie: L'Espace littéraire, Paris 1955 (Éditions Gallimard).

${ }^{15}$ Zob.: H. White, Dyskurs europejski i poszukiwanie europejskiej tożsamości, przeł. S. Masłon, W. Drąg, http://www.postcolonial-europe.eu/pl/essays/93--the-discourse-of-europe-and-the -search-for-a-european-identity [dostęp: 4 października 2016].

${ }^{16}$ Zob.: J. Hillis Miller, O literaturze, przeł. K. Hoffman, Poznań 2014, s. 13 i n.
} 
literaturę. Zdarza się tak, nawet jeśli wielu z nich było wykształconych w duchu staromodnej historii literatury i uważnego czytania (close reading) kanonicznych tekstów ${ }^{17}$.

Chciałbym nawet napisać, że słowa te brzmią złowróżbnie i ciągle we współczesnych praktykach interpretacyjnych znajdują swoje egzemplifikacje, ciągle się ,samo-aktualizują”. Myślę tu o „falach” inspirowanych zmieniającymi się modami (rzadziej: fascynacjami), pracami filozofów, antropologów, socjologów, psychoanalityków, neomarksistów...

Jednak z literaturoznawczego punktu widzenia najcenniejsze wydają się uwagi autora Piatego poematu na temat metafory jako istoty poezji. Naiwne nadzieje, że „kiedyś polscy Disneye” potraktują ballady i sonety Mickiewicza, epopeje Słowackiego, wiersz Bema pamięci żałobny rapsod Norwida oraz Hymny Kasprowicza jako ,gotowe scenariusze filmowe" (Nowoczesność w tradycji, JP, s. 51-52), przeplatają się tu z wnikliwą analizą nowoczesnej metafory i modernistycznego sposobu obrazowania w poezji. Podobnie szczegółowa jest analiza roli rytmu i rymu w poezji. Ale najbardziej oryginalną tezą szkicu są utyskiwania nad brakiem średniowiecza w tradycji polskiej poezji jako główną przyczyną jej słabości i traktowania przez czytelników, krytyków i badaczy literatury awangardowych poetów usiłujących sięgać po tę tradycję jako światoburców i heretyków:

Wśród Polaków, ze smutkiem trzeba wyznać, każda próba oryginalnej wypowiedzi, choćby nawet najbardziej po linii rozwojowej poezji europejskiej idąca, spotyka się zazwyczaj z posądzeniem o światoburcze nowatorstwo, o herezję, którą wykląć uroczyście należy. Czytelnikowi polskiemu brak perspektywy, tak jak brak tej perspektywy i równowagi polskiemu krytykowi. Równowaga została zachwiana przed wiekami. Literaturze naszej brak Średniowiecza (Nowoczesność w tradycji, JP, s. 65).

Ponownie mogę tu wskazać na paralelę z późniejszymi sądami Aleksandra Wata i Czesława Miłosza, przy czym muszę raz jeszcze przypomnieć, że swój esej pisał Pietrkiewicz w 1946 roku, a podobne myśli na temat braku tradycji średniowiecznej w rozwoju polskiego języka poetyckiego formułowali w esejach i pamiętnikach autor Ciemnego świecidła oraz we wstępie do własnych przekładów psalmów autor Zniewolonego umy$s ł u$ wiele lat później ${ }^{18}$.

I jeszcze - już na koniec — pojawiające się w konkluzji Nowoczesności $w$ tradycji teza: „Studia z zakresu literatury stają się obecnie studiami p orównaw c zy mi”; „Jednotorowe historie literatur należą do przeżytków" (Nowoczesność $w$ tradycji, JP, s. 70, podkreśl. - J. O.), która przecież powróciła w zorientowanych kulturowo współczesnych badaniach literackich, a nie była też odległa od teoretycznego i komparatystycznego projektu René Welleka i Austina Warrena ${ }^{19}$.

Wymieniłem tu - skrótowo i pobieżnie, jako wprowadzenie do głębszego namysłu — szereg obserwacji Pietrkiewicza, które powróciły w literaturoznawczej i humanistycznej refleksji po postmodernistycznym przełomie i stają się współcześnie rodzajem aksjomatów, bo w czasie gdy powstawały, nie były przedmiotem poważnych dyskusji, przynajmniej w polskim literaturoznawstwie. Może zresztą nie o przełomach czy zwro-

\footnotetext{
17 Tamże, s. 20.
}

18 Zob.: A. Wat, Dziennik bez samogłosek, oprac. K. i P. Pietrychowie, Warszawa 2001, np. s. 56, 268-269, 318-319; Księga psalmów, przeł. Cz. Miłosz, Paryż 1982, s. 43-52.

${ }^{19}$ Podręcznik Theory of Literature ukazał się w 1942 roku, zaś polski przekład pod redakcją Macieja Żurowskiego - w 1975 roku (zob.: R. Wellek, A. Warren, Teoria literatury, przeł. J. Krycki, I. Sieradzki, M. Żurowski, redakcja przekładu M. Żurowski, Warszawa 1975; pierwsze wydanie: R. Wellek, A. Warren, Theory of Literature, New York 1942). 
tach w nauce o literaturze i szerzej - humanistyce - trzeba mówić? Może trzeba traktować literaturę, naukę o niej, humanistykę, jako wielonurtowy, rozgałęziający się strumień czy jako nawarstwiający się palimpsest, w którym ciągle wracają te same pytania, problemy, tezy?... Nie znalazłem też w literaturze, krytyce literackiej i badaniach literackich śladów, by eseistyka Pietrkiewicza, a szczególnie właściwie programowy szkic Nowoczesność w tradycji, miał recepcję uprawniającą do tezy, iż Pietrkiewicz wywarł jakiś istotny wpływ na poezję, krytykę i literaturoznawstwo drugiej połowy XX i pierwszych dekad XXI wieku. Być może - ale wymaga to starannych badań — odegrał on rolę w kształtowaniu się poetyki londyńskiej grupy „Kontynenty”. Niewiele $\mathrm{w}$ zakresie recepcji zmieniła staranna edycja publicystyki Pietrkiewicza przygotowana przez Barbarę Czarnecką $(2002)^{20}$ czy zbiór jego - napisanych po angielsku i przełożonych na język polski - studiów komparatystycznych $(1986)^{21}$.

Może trzeba nam do lektury tych fragmentów wrócić, może trzeba je na nowo przemyśleć?... Bez złudzeń, że da się umiejscowić refleksję estetyczną, teoretyczną i historycznoliteracką Pietrkiewicza w głównym nurcie humanistyki polskiej czy europejskiej. Ale z pewnością, że spełnia się w ten sposób badawczy obowiązek, „obowiązek wobec literatury polskiej”, jak swoje uczestnictwo w literaturze określił w znakomitym, moim zdaniem, eseju Czesław Miłosz. Książki Jerzego Pietrkiewicza czekają na swojego czytelnika, jak to książki — taka ich rola... Także jego publicystyka, głos według mnie, ,niewysłuchany”, ale jednak ważny. Jego przypomnienie chce być niewielkim uzupełnieniem obrazu polskiej literatury nowoczesnej i współczesnej literatury emigracyjnej.

\section{LITERATURA}

Blanchot M., Przestrzeń literacka, przeł. T. Falkowski, Warszawa 2016.

Bolecki W., Polowanie na postmodernistów (w Polsce), Kraków 1998.

Danilewicz-Zielińska M., Szkice o literaturze emigracyjnej, Paryż 1978.

Gombrowicz W., Dziennik 1953-1956, red. J. Błoński, Kraków 1986.

Hillis Miller J., O literaturze, przeł. K. Hoffman, Poznań 2014.

Ksiega psalmów, przeł. C. Miłosz, Paryż 1982.

Literatura polska na obczyźnie 1940-1960, t. 1-2, red. T. Terlecki, Londyn 1965.

de Man P., Liryka i nowoczesność, „Literatura na świecie” 1999, nr 10/11.

Mickiewicz A., Ksieggi narodu polskiego i pielgrzymstwa polskiego, Rzym 1946.

Miłosz C., Noty o wygnaniu, „Kultura” 1981, nr 3 (402).

Miłosz C., Prywatne obowiązi, Paryż 1972.

Pietrkiewicz J., Dla pokrzepienia mózgów. Szkice literackie z lat 1940-1948. Nowoczesność w tradycji. Essay o poezji. Trust the trees, wybór B. Czarnecka, Torun 2002.

Pietrkiewicz J., Literatura polska w perspektywie europejskiej: studia i rozprawy, przeł. A. Olszewska-Marcinkiewicz, I. Sieradzki, wybór i oprac. J. Starnawski, Warszawa 1986.

Pietrkiewicz J., Pogrzeb Europy, Londyn 1946.

Pisarz na obczyźnie, red. T. Bujnicki, W. Wyskiel, Wrocław-Warszawa-Kraków-Gdańsk-Lódź 1985.

Wańkowicz M., Klub Trzeciego Miejsca, Paryż 1949.

Wat A., Dziennik bez samogłosek, oprac. K. i P. Pietrychowie, Warszawa 2001.

Wellek R., Warren A., Teoria literatury, przeł. J. Krycki, I. Sieradzki, M. Żurowski, Warszawa 1975.

${ }^{20}$ J. Pietrkiewicz, Dla pokrzepienia mózgów...

${ }^{21}$ Tenże, Literatura polska w perspektywie europejskiej: studia i rozprawy, przeł. A. Olszewska-Marcinkiewicz, I. Sieradzki, wybór i oprac. J. Starnawski, Warszawa 1986. 
White H., Dyskurs europejski i poszukiwanie europejskiej tożsamości, przeł. S. Masłoń, W. Drąg. http://www.postcolonial-europe.eu/pl/essays/93--the-discourse-of-europe-and-the-searchfor-a-european-identity (dostęp: 4 października 2016).

Wierzyński K., Poezja polska na emigracji, „Wiadomości Polskie, Polityczne i Literackie” 1943, nr 41 (187).

Wittlin J., Orfeusz w piekle XX wieku, Paryż 1963.

\section{THE EMIGRÉ ESSAYS OF JERZY PIETRKIEWICZ}

The article offers an analysis of Jerzy Pietrkiewicz's comments on Polish literature, in particular his remarks on the nature of the relation between poetry and European identity, religion and technological development. Moreover, it demonstrates that some of Pietrkiewicz's insights preceded the well-known statements made later by literary theorists and writers themselves.

KEY WORDS: Jerzy Pietrkiewicz, immigrant poetry, tradition, identity.

SŁOWA KLUCZOWE: Jerzy Pietrkiewicz, poezja emigracyjna, tradycja, tożsamość. 